\title{
The Assessment of the Eutrophication Degree in Selected Surface Waters of the Poprad Catchment
}

\section{Introduction}

Eutrophication, according to the Directive 91/271/EEC, referring to the treatment of municipal wastewaters, is defined in the following way:

Eutrophication means enrichment of water with the compounds of nitrogen and/or phosphorus, causing the accelerated growth of algae and higher plants, which causes undesirable disturbances of biological equilibrium among aquatic organisms and the quality of the discussed waters.

To carry out the analysis of water a test kit - JBL TESTLAB was used to study water parameters. Owing to its small size and, consequently, its portability, water analysis could be done in situ.

The kit consists of nine different water tests of a wide spectrum:

- test GH - general hardness,

- test $\mathrm{KH}$ - carbonate hardness,

- test pH 3-10 - general acidity of water,

- test pH 6.7-7.6 - water acidity - more accurate measurement,

- test $\mathrm{NO}_{2}$ - the content nitrites,

- test $\mathrm{NO}_{3}$ - the content nitrates,

- test $\mathrm{Fe}$ - the content iron,

- test $\mathrm{NH}_{4}$ - the content of ammonia,

- test $\mathrm{PO}_{4}$ - the content of phosphates,

In the set there are glass burettes, thermometer, syringes, plastic spatulas, scales of colours, and tables to record the results of the analyses (Fig. 1).

* AGH University of Science and Technology, Faculty of Energy and Fuels, Krakow, Poland 


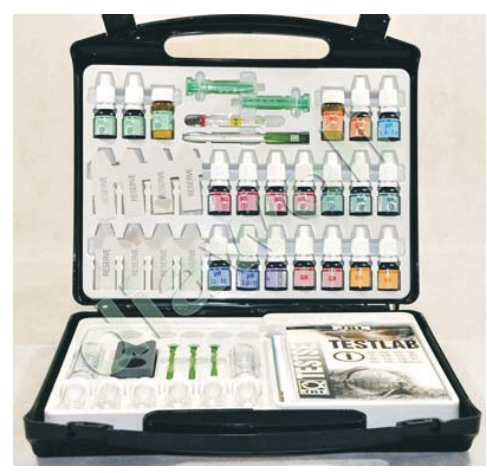

Fig. 1. Test kit JBL TESTLAB

\section{The Methods and Place of Sampling}

One of the most important tasks of qualitative water analysis is taking a representative sample, according to certain procedures of sampling, because errors made at the stage of sampling cannot be corrected in the later analyses. Thus, sampling is a process having fundamental meaning for correctness of the obtained results and was carried out according to the following standards:

- Polish Standard PN-EN ISO 5667-1:2008: Water Quality - Sampling - Part 1,

- Polish Standard PN-EN ISO 5667-6:2003, Polish Standard - Sampling - Part 6.

Figure 2 presents places where samples were taken. In table 1 the sample numbers were put together with the place of sampling and the name of the river/stream the sample was taken from.

Table 1. Places of sampling

\begin{tabular}{|c|c|c|}
\hline Sample No. & Place of Sampling & The Name of the River/Stream \\
\hline 1 & Stary Sącz - Stream Gauge Biegonice & \multirow{11}{*}{ Poprad } \\
\hline 2 & Below Rytro - Bridge Rzeczanów & \\
\hline 3 & Above Piwniczna & \\
\hline 4 & Wierchomla Wielka - Outlet to Poprad & \\
\hline 5 & Below Żegiestów & \\
\hline 6 & Milki & \\
\hline 7 & Below Muszyna - Waste water Treatment Plant & \\
\hline 8 & Muszyna - Outlet of Szczawnik to the Poprad Rivier & \\
\hline 9 & Muszyna - Outlet of Muszynka to the Poprad River & \\
\hline 10 & Leluchów & \\
\hline 11 & Circ & \\
\hline
\end{tabular}


Table 1. cont

\begin{tabular}{||c|c|c|}
\hline Sample No. & Place of Sampling & The Name of the River/Stream \\
\hline \hline 12 & Powroźnik - below the Outlet of Kryniczanka & \multirow{2}{*}{ Muszynka } \\
\hline 13 & Below Krynica - Czarny Most & \\
\hline 14 & Below Krynica & \multirow{2}{*}{ Muszynka } \\
\hline 15 & Above Krynica & \\
\hline 16 & Mochnaczka - Outlet to Muszynka &
\end{tabular}

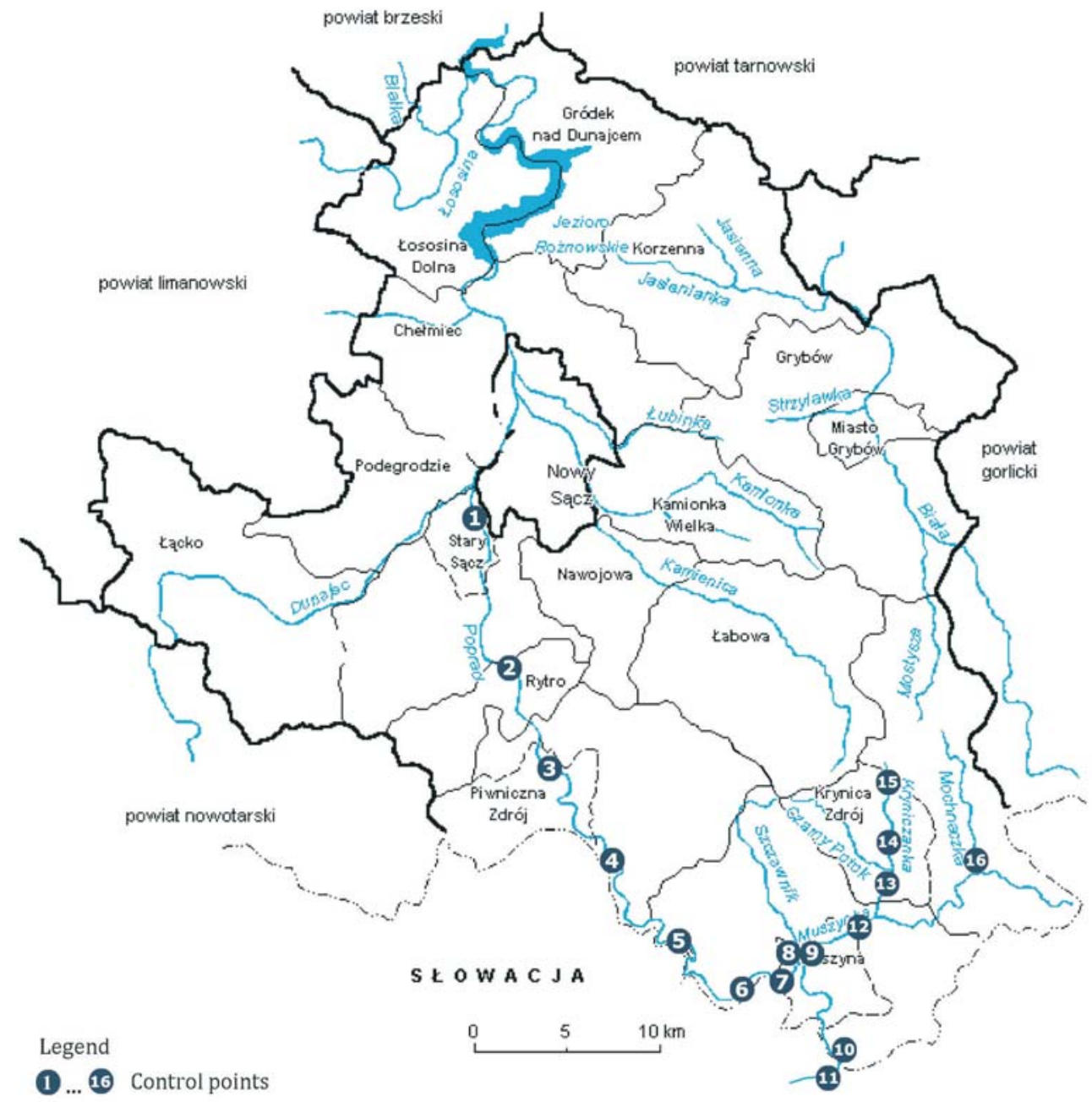

Fig. 2. Sampling points 


\section{Results}

Four sampling series were done (two in the spring - in April and May and two others in the autumn - in October and November). The results of the carried out series of measurements were put together in tables, each series was put in as separate table (Tabs 2-5).

Additionally, for the sake of more accurate analysis, the results of 2 series were presented in a graph for each season (Figs 3-6).

Table 2. The results of the measurements of the contents of nitrates and phosphates April 2011

\begin{tabular}{|c|c|c|c|}
\hline Sample No. & Reaction & $\begin{array}{l}\text { Nitrates } \\
{\left[\mathrm{mg} / \mathrm{dm}^{3}\right]}\end{array}$ & $\begin{array}{l}\text { Phosphates } \\
{\left[\mathrm{mg} / \mathrm{dm}^{3}\right]}\end{array}$ \\
\hline 1 & 8.6 & 5.00 & 0.10 \\
\hline 2 & 8.8 & 7.50 & 0.30 \\
\hline 3 & 8.8 & 5.00 & $0.05^{*}$ \\
\hline 4 & 8.2 & 7.50 & 0.25 \\
\hline 5 & 8.2 & 8.50 & 0.25 \\
\hline 6 & 8.2 & 8.50 & 0.20 \\
\hline 7 & 8.2 & 8.50 & 0.30 \\
\hline 8 & 8.0 & 7.50 & 0.25 \\
\hline 9 & 7.9 & 7.50 & 0.20 \\
\hline 10 & 8.5 & 7.00 & $0.05^{*}$ \\
\hline 11 & 8.6 & 7.50 & $0.05^{*}$ \\
\hline 12 & 8.1 & 7.50 & 0.25 \\
\hline 13 & 7.4 & 7.50 & 0.20 \\
\hline 14 & 7.8 & 7.50 & 0.30 \\
\hline 15 & 8.1 & 7.50 & $0.05^{*}$ \\
\hline 16 & 7.4 & 4.00 & $0.05^{*}$ \\
\hline
\end{tabular}

\footnotetext{
* Slight colouration was detected.
} 
Table 3. The results of the measurements of the contents of nitrates and phosphates May 2011

\begin{tabular}{|c|c|c|c|}
\hline Sample No. & Reaction & $\begin{array}{c}\text { Nitrates } \\
{\left[\mathrm{mg} / \mathrm{dm}^{3}\right]}\end{array}$ & $\begin{array}{c}\text { Phosphates } \\
{\left[\mathrm{mg} / \mathrm{dm}^{3}\right]}\end{array}$ \\
\hline 1 & 7.6 & 5.00 & 0.20 \\
\hline 2 & 7.8 & 7.50 & 0.20 \\
\hline 3 & 8.7 & 4.00 & 0.10 \\
\hline 4 & 8.4 & 7.00 & 0.20 \\
\hline 5 & 8.3 & 7.00 & 0.20 \\
\hline 6 & 8.3 & 8.00 & 0.25 \\
\hline 7 & 7.8 & 8.00 & 0.20 \\
\hline 8 & 8.2 & 8.00 & 0.10 \\
\hline 9 & 8.2 & 8.00 & 0.10 \\
\hline 10 & 8.8 & 7.00 & $0.05^{*}$ \\
\hline 11 & 8.9 & 6.00 & 0.20 \\
\hline 12 & 8.1 & 7.50 & 0.30 \\
\hline 13 & 7.8 & 7.00 & $0.05^{*}$ \\
\hline 14 & 7.6 & 5.00 & 0.10 \\
\hline 15 & 8.1 & 5.50 & 0.10 \\
\hline 16 & 7.9 & 4.00 & $0.05^{*}$ \\
\hline
\end{tabular}

* Slight coloration was noticed.
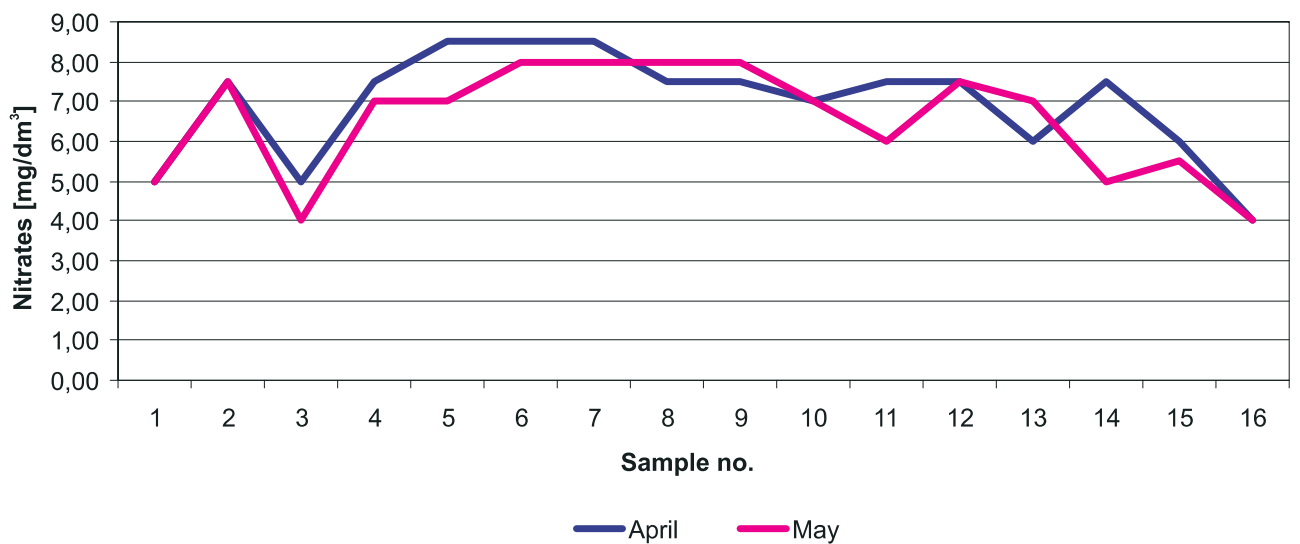

Fig. 3. The level of nitrates - spring 


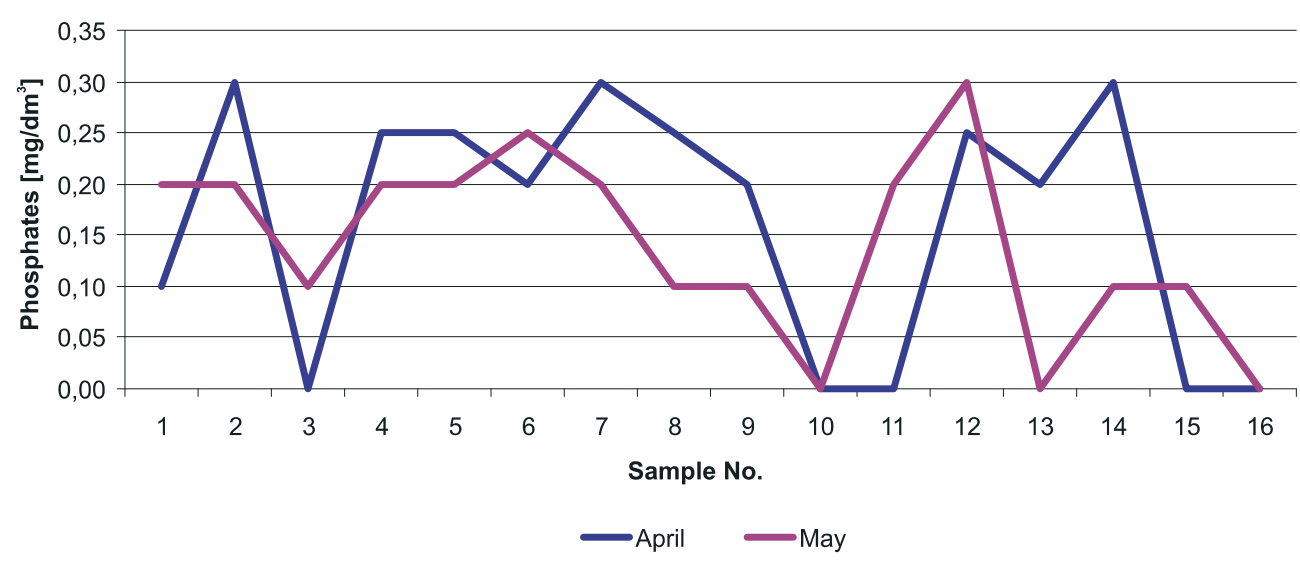

Fig. 4. The level of phosphates - spring

Table 4. The results of the measurements of the contents of nitrates and phosphates October 2011

\begin{tabular}{|c|c|c|c|}
\hline Sample No. & Reaction & $\begin{array}{l}\text { Nitrates } \\
{\left[\mathrm{mg} / \mathrm{dm}^{3}\right]}\end{array}$ & $\begin{array}{c}\text { Phosphates } \\
{\left[\mathrm{mg} / \mathrm{dm}^{3}\right]}\end{array}$ \\
\hline 1 & 8.7 & 5.00 & $0.05^{*}$ \\
\hline 2 & 8.3 & 8.50 & 0.25 \\
\hline 3 & 8.5 & 5.00 & 0.10 \\
\hline 4 & 8.5 & 5.00 & $0.05^{*}$ \\
\hline 5 & 8.4 & 8.00 & 0.20 \\
\hline 6 & 8.3 & 8.00 & 0.20 \\
\hline 7 & 8.4 & 8.50 & 0.30 \\
\hline 8 & 8.0 & 9.50 & 0.80 \\
\hline 9 & 7.7 & 9.50 & 0.20 \\
\hline 10 & 8.3 & 5.50 & 0.10 \\
\hline 11 & 8.3 & 8.00 & 0.50 \\
\hline 12 & 8.2 & 5.50 & 0.20 \\
\hline 13 & 7.6 & 7.00 & 0.10 \\
\hline 14 & 7.9 & 7.00 & 0.80 \\
\hline 15 & 8.2 & 5.50 & 0.10 \\
\hline 16 & 8.0 & 4.00 & $0.05^{*}$ \\
\hline
\end{tabular}

\footnotetext{
* Slight coloration was noticed.
} 
Table 5. The results of the measurements of the contents of nitrates and phosphates November 2011

\begin{tabular}{|c|c|c|c|}
\hline Sample No. & Reaction & $\begin{array}{c}\text { Nitrates } \\
{\left[\mathrm{g} / \mathrm{dm}^{3}\right]}\end{array}$ & $\begin{array}{c}\text { Phosphates } \\
{\left[\mathrm{g} / \mathrm{dm}^{3}\right]}\end{array}$ \\
\hline 1 & 8.7 & 5.50 & $0.05^{*}$ \\
\hline 2 & 8.9 & 8.00 & 0.20 \\
\hline 3 & 8.5 & 5.00 & 0.60 \\
\hline 4 & 8.2 & 8.50 & 0.20 \\
\hline 5 & 8.4 & 8.50 & 0.20 \\
\hline 6 & 8.3 & 7.00 & 0.20 \\
\hline 7 & 8.7 & 7.50 & 0.20 \\
\hline 8 & 7.9 & 9.50 & 0.60 \\
\hline 9 & 7.9 & 9.50 & 0.60 \\
\hline 10 & 8.3 & 4.00 & 0.60 \\
\hline 11 & 8.4 & 7.50 & 0.30 \\
\hline 12 & 8.1 & 5.50 & 0.30 \\
\hline 13 & 7.8 & 5.50 & 0.20 \\
\hline 14 & 7.8 & 6.50 & 0.60 \\
\hline 15 & 8.2 & 5.50 & $0.05^{*}$ \\
\hline 16 & 8.1 & 4.00 & $0.05^{*}$ \\
\hline
\end{tabular}

* Slight coloration was noticed.

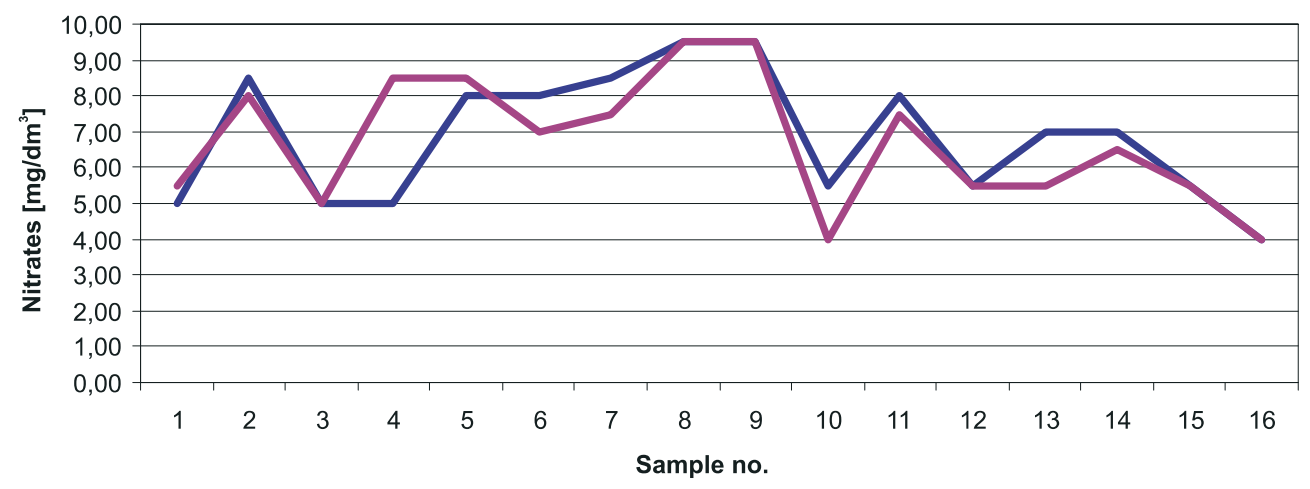

October November

Fig. 5. The level of nitrates - autumn 


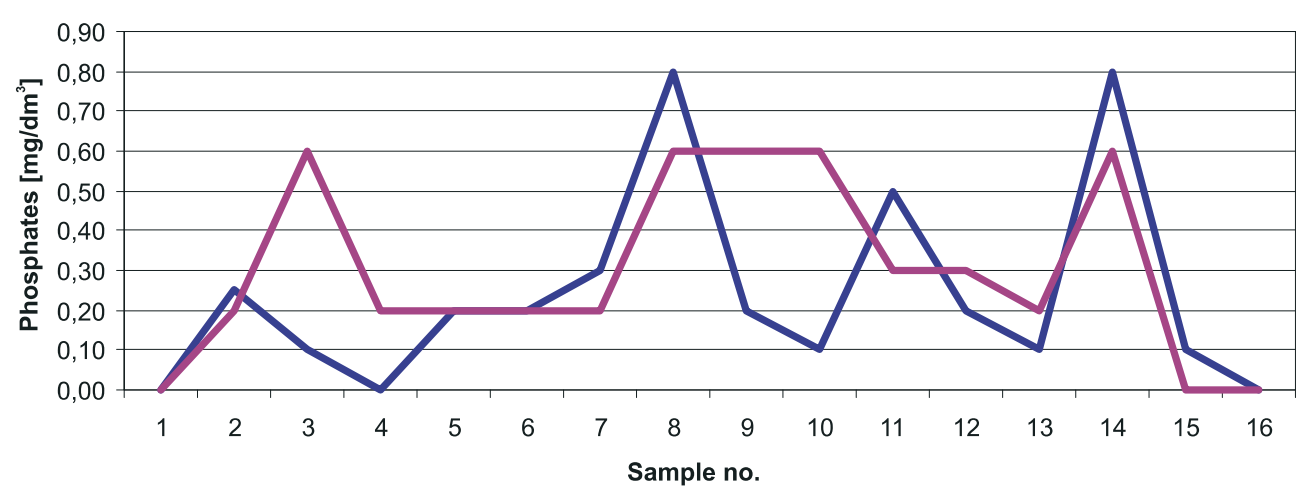

October November

Fig. 6. The level of phosphates - autumn

\section{Statistical Analysis of the Results}

The results of statistic analysis of measurements are shown in tables 6 and 7 .

Table 6. Selected statistical parameters for spring samples

\begin{tabular}{|c|c|c|c|}
\hline \multirow[b]{2}{*}{ Statistic Parameter } & \multicolumn{3}{|c|}{ Spring } \\
\hline & reaction & $\begin{array}{l}\text { nitrates } \\
{\left[\mathrm{mg} / \mathrm{dm}^{3}\right]}\end{array}$ & $\begin{array}{c}\text { phosphates } \\
{\left[\mathrm{mg} / \mathrm{dm}^{3}\right]}\end{array}$ \\
\hline Mean & 8.2 & 6.73 & 0.20 \\
\hline Maximum & 8.9 & 8.50 & 0.30 \\
\hline Minimum & 7.4 & 4.00 & 0.10 \\
\hline Median & 8.2 & 7.25 & 0.20 \\
\hline Standard Deviation & 0.4 & 1.38 & 0.07 \\
\hline
\end{tabular}

Table 7. Selected statistical parameters for autumn samples

\begin{tabular}{||l|c|c|c|}
\hline \multirow{2}{*}{ Statistic Parameter } & \multicolumn{3}{|c|}{ Autumn } \\
\cline { 2 - 4 } & reaction & $\begin{array}{c}\text { nitrates } \\
{\left[\mathrm{mg} / \mathrm{dm}^{3}\right]}\end{array}$ & $\begin{array}{c}\text { phosphates } \\
{\left[\mathrm{mg} / \mathrm{dm}^{3}\right]}\end{array}$ \\
\hline \hline Mean & 8.2 & 6.78 & 0.33 \\
\hline Maximum & 8.9 & 9.50 & 0.80 \\
\hline Minimum & 7.6 & 4.00 & 0.10 \\
\hline Median & 8.3 & 7.00 & 0.20 \\
\hline Standard Deviation & 0.3 & 1.76 & 0.22 \\
\hline
\end{tabular}


The goal of this paper was to define the degree of eutrophication for selected surface streams and rivers of the Poprad Catchment, caused by the released agricultural pollutants in the Nowy Saccz District. The studies lasted 12 months. During that period - in 16 points distributed on 3 rivers/streams, in four measurement series, 64 water samples were collected, following standard procedures and analysed. The content of nitrates, phosphates, and the reaction were defined by the portable test kit JBL TESTLAB.

In the studied places the main sources of the pollution of rivers and streams with nutrients include the non-point sources, i.e. the areas of agricultural outflows. They contain nutrients from artificial fertilizers, pesticides, as well as animal production. The identification of non-point pollution sources, coming from agricultural land use as well as animal production is difficult, and so is the control of the inflow.

The carried out analysis of water, based on the Enactment of the Minister of Environment of 23rd December 2002 on the criteria of the determination of waters sensitive to the pollution of nitrogen from agricultural sources (Dz. U. 2002 No. 241, position 2093) showed that in the Poprad Catchment, covering the area of the Nowy Sacz District, there are no waters polluted or threatened with pollution with nitrogen compound from agricultural sources, where the content of nitrates would be $40-50 \mathrm{mg} \mathrm{NO} / \mathrm{dm}^{3}$ or above $50 \mathrm{mg} \mathrm{NO} / \mathrm{dm}^{3}$. The waters of the Poprad and its tributaries do not indicate the features of the eutrophication originating from farming and agriculture. The concentrations of indexes applied during the assessment of the eutrophication of surface waters such as: nitrates and phosphates did not exceed limit values, above which the eutrophication of waters occur. The mean content of nitrates and phosphates in the spring was $6.73 \mathrm{mg} / \mathrm{dm}^{3}$ and $0.20 \mathrm{mg} / \mathrm{dm}^{3}$, respectively and in the autumn $6.78 \mathrm{mg} / \mathrm{dm}^{3}$ and $0.33 \mathrm{mg} / \mathrm{dm}^{3}$. The level of nitrates for these two seasons was more or less equal, the only difference was in the level of phosphates, which was clearly higher in the autumn - by as much as 0.13 , which makes $65 \%$.

There are many ways to limit the process of the eutrophication of waters. One is the management of the catchment, so that the load of nutrients to waters is limited. This action it to (among others) form the agricultural landscape with the use of tree stands between fields, as well as carrying out water management, according to the rules of good practice in agriculture. Good practice in agriculture is understood as: not using artificial fertilizers in the periods when fertilization is not recommended; the application of fertilizers according to the fertilizing plan; following the rules of fertilizing soils situated near waters, as well as on steep slopes; management of grounds and the organization of production, regarding such things as crop rotation; not to fertilize soils that are muddy, flooded with water, covered with snow or frozen; storing natural fertilizers, such as manure and slurry 
allowing the preservation of periods when fertilization is not recommended. Following these rules will limit the transfer of nutrients and facilitate marking and controlling the places of the inflow of these elements to waters.

\section{References}

[1] Rozporzadzenie Ministra Środowiska z dnia 23 grudnia 2002 r. w sprawie kryteriów wyznaczania wód wrażliwych na zanieczyszczenia zwiazkami azotu ze źródet rolniczych. Dz. U. z 2002 r. Nr 241, poz. 2093.

[2] Ilnicki P., Górecki K., Melcer B.: Eutrofizacja cieków wodnych zlewni Warty w latach 1992-2002. Wydawnictwo Uniwersytetu Poznańskiego, Poznań 2008.

[3] Dyrektywa Rady z dnia 21 maja 1991 r. dotycząca oczyszczania ścieków komunalnych (91/271/EWG). Dz. U. L. 135/40 z 30.05.1991.

[4] Stan środowiska powiatu nowosadeckiego w 2002 roku. [in:] Program ochrony środowiska dla powiatu nowosadeckiego na lata 2004-2011, Nowy Sącz 2004.

[5] Raport o stanie środowiska w województwie małopolskim w 2008 roku. Biblioteka Monitoringu Środowiska, Wojewódzki Inspektorat Ochrony Środowiska, Kraków 2009.

[6] Program ochrony środowiska dla powiatu nowosadeckiego na lata 2004-2011, Nowy Sącz 2004.

[7] Rozporzadzenie Ministra Środowiska z dnia 27 listopada 2002 r. w sprawie wymagań, jakim powinny odpowiadać wody powierzchniowe wykorzystywane do zaopatrzenie ludności wodę przeznaczona do spożycia. Dz. U. Nr 204, poz. 1728.

[8] Rozporzadzenie Ministra Środowiska z dnia 4 października 2002 r. w sprawie wymagań, jakim powinny odpowiadać wody śródladowe będace środowiskiem życia ryb w warunkach naturalnych. Dz. U. Nr 176 Poz. 1455.

[9] PN-EN ISO 5667-1:2008: Jakość wody - Pobór próbek - Część 1: Wytyczne opracowania programów pobierania próbek $i$ technik pobierania próbek.

[10] PN-EN ISO 5667-6:2003: Jakość wody - Pobór próbek - Część 6: Wytyczne dotyczace pobierania próbek $z$ rzek $i$ strumieni. 